(4) Acetic acid.

The residue $(\mathrm{C})$ is evaporated to dryness, added with phosphoric acid to set volatile acid free and distilled. The distillate, on treatment with yellow mercuric oxide, gives white mercuric acetate.

$0.0620 \mathrm{~g}$. subst. gave $0.0152 \mathrm{~g}$. $\mathrm{SHg}_{\mathrm{g}}$.

Calculated for $\mathrm{C}_{4} \mathrm{HI}_{6} \mathrm{O}_{4} \mathrm{Hg} \quad \mathrm{Hg} 62.96 \%$.

Found

$\mathrm{Hg} 62.84 \%$.

III. Quantitative determination of fermentation products.

The four substances above described were identified as the fermentation products, but the latter three were produced in so small amounts that I determined quantitatively only ethyl alcohol by the ordinary distillation method.

The conditions of culture are all the same as mentioned above (see I) except the quantity of peptone, the source of nitrogen, which is indicated by the following table.

\begin{tabular}{|c|c|c|c|c|}
\hline $\begin{array}{c}\text { Quantity of } \\
\text { peptone in } \\
100 \mathrm{ccm} \text { of medium. }\end{array}$ & $\begin{array}{l}\text { Glucose : } \\
\text { Peptone. }\end{array}$ & $\begin{array}{l}\text { Maximum } \\
\text { yield. }\end{array}$ & $\begin{array}{l}\text { Days after } \\
\text { inoculation. }\end{array}$ & $\begin{array}{l}\text { Wt. of } \\
\text { fungus. }\end{array}$ \\
\hline $0.1 \mathrm{~g}$ & $100: 1$ & $3.00 \mathrm{vol} \%$ & 31 & $0.11 \mathrm{~g}$. \\
\hline $0.5 \mathrm{~g}$ & $100: 5$ & $4.29 \quad \prime \prime$ & 19 & $0.26 \mathrm{~g}$. \\
\hline $1.0 \mathrm{~g}$. & $100: 10$ & $4.18 \quad \prime$ & 16 & $0.36 \mathrm{~g}$ \\
\hline $3.0 \mathrm{~g}$. & $100: 30$ & 1.82 & 14 & $0.57 \mathrm{~g}$. \\
\hline $5.0 \mathrm{~g}$. & $100: 50$ & $1.20 \quad / \prime$ & 12 & $0.58 \mathrm{~g}$. \\
\hline
\end{tabular}

IV. Conclusion.

It has been found that ethyl alcohol is the greater part of fermentation products from glucose and also a small amount of succinic acid, slight quantities of acetic acid and acetaldehyde are produced along with ethyl alcohol. $3.40 \mathrm{~g}$. of ethyl alcohol is the maximum yield from $10 \mathrm{~g}$. of glucose when the ratio of glucose to peptone is about 20 to $\mathrm{I}$.

\title{
ON THE DIFFERENCES OF THE BREWING BARLEY ACCORDING TO SPECIES.
}

\section{THE INVESTIGATIONS OF THE PROTEINS.}

By Yukihiko Nakamura.

(Received Dec. 10th., 1926.)

\section{Introduction.}

The use of barley in Japan is very wide, not only as food for man, and 
farm animals, but also for the brewing of beer. The amount of its consumption especially for the brewer's purpose, with the improvement of the fermentation industry, increases year after year. Consequently, barley is now ranking among the more important products in our agricultural world. From statistics, it can be seen that the production of barley in this country is about $8,800,000$ Koku valued at $10,000,000$ Yen per annum and from the standpoint of the technical industry, the amount of thc consumption of barley for brewing is the largest. The import of malt is disproportionately larger than the import of barley, indicating that there must be some differences in the barley and the malt produced at home and abroad. The very large amount of consumption of barley for brewing purposes tells us how a study of the barley might be useful for the brewing. Recentry some authors were able to find out the physico-chemical specificities of oryzenins according to the varieties of the rice. The present investigation is aimed to find out, if any, marked specificities in the proteins of the barley.

Investigations upon barley which have hitherto been carried out and are already numerous, can be classified into 9 parts; (1) upon the method of the estimation, (2) upon the nutrition and the nutritive value, (3) upon the relations among the soil, the manure and the growth of the plant, (4) upon the relations between the growing period and the constituents of the plant, (5) upon the fermentation, (6) upon the starches, (7) upon the fats, (8) upon the proteins and (9) upon the enzymes.

But concerning the protein and the fermentation of the barley, almost all the investigations are limited to the determinations of the hydrolyses products of the proteins, or the results of feeding experiments with the proteins. The effects of the species of the barley upon the proteins or the differences of the proteins derived from the different species of the barley are not yet studied. If the problem could be made clear and the effects of the different species of the barley were known, it would tell us another way and direction of agricultural planning.

\section{Conclusions.}

The barley widely used among the brewer in this conutry are Golden Melon, Chevalier and Hokudai No. 1, so the present investigation was carried out with these 3 species of barley. The results of the present physicochemical and chemical investigations of the proteins obtained from these 3 species of barley, using the yield of three successive years, are as follows :-

(1) Using 1,000 kernels each, no regular relationship could be found among the characters of the three species of barley, so far as they concern weight and specific gravity of the barley grains. 
(2) On the chemical analyses of the powder of the grains, the total nitrogen and the protein nitrogen content are the least in Golden Melon, and the most in Chevalier with Hokudai No. 1 lying between the two.

(3) The isolation and determination of four kinds of nitrogen of these three species always shows the smallest amount of nitrogen soluble in $10 \%$ $\mathrm{NaCl}$ solution and the amount increases according to the order of the water soluble, the $70 \%$ alcohol solution soluble and the $0.2 \% \mathrm{NaOH}$ solution soluble nitrogen.

The quantities of $10 \% \mathrm{NaCl}$ solution soluble nitrogen decrease in the order Golden Melon, Hokudai No. 1 and Chevalier. The 0,2 \% $\mathrm{NaOH}$ solution soluble nitrogen decreases in the order Hokudai No. 1, Golden Melon and Chevalier.

(4) The ash content of the proteins increases in the order, hordein, 10 $\% \mathrm{NaCl}$ solution soluble protein and glutenin. As for the species of the barley, Golden Melon has the minimum ash content, Chevalier medium, and Hokudai No. 1 the maximum. This appears to be a constant relation found among the species of the barley and among the kinds of the proteins.

(5) Among the species of the barley, there is a tendency that the content of carbon and hydrogen of the protein always follow and that of oxygen is always contrary. The content of the nitrogen of the protein is markedly different among the species of the barley. That of the $10 \% \mathrm{NaCl}$ solution soluble protein and the glutenin is the maximum in Hokudai No. 1, medium in Chevalier and the minimum in Golden Melon while that of the hordein is maximum in Golden Melon, medium in Chevalier and minimum in Hokudai No. 1. The content of the nitrogen of the hordein is the smallest, the glutenin medium and the $10 \% \mathrm{NaCl}$ solution soluble protein the maximum.

The sulphur content of the proteins is not regular, but it ean be seen that of the hordein is the highest and the glutenin the lowest.

(6) The amount of free amino nitrogen of the $10 \% \mathrm{NaCl}$ solution soluble protein is the greatest in Golden, medium in Hokudai No. 1 and the smallest in Chevalier, and that of the glutenin, the greatest in Chevalier, medium in Golden Melon and the smallest in Hokudai No. 1. The amount of free amino nitrogen of the hordein is always greater in Chevalier than in Hokudai No. 1, and in Golden Melon it is irregular. The hordein contains less free amino nitrogen than the $10 \% \mathrm{NaCl}$ solution soluble protein and the glutenin, while the $10 \% \mathrm{NaCl}$ solution soluble protein seem to contain more than the glutenin.

(7) Differences are observed among the content of the hydrolytic products of the $10 \% \mathrm{NaCl}$ solution soluble protein, of the hordein and of 
the glutenin according to the species of the barley.

(8) The changes of the turbidity and the surface tension of the protein in an alkaline solution when titrated with $\mathrm{HCl}$ are observed. In the case of the water soluble protein, the maximum quantity of $\mathrm{HCl}$ in order to attain greatest surface tension and turbidity is required by Golden Melon, and in the case of the $10 \% \mathrm{NaCl}$ solution soluble protein, the required quantities of $\mathrm{HCl}$ are decreased in the order Hokudai No. 1, Chevalier and Golden Melon. In the case of the hordein, that of Golden Melon requires the maximum amount of $\mathrm{HCl}$, next Hokudai No. 1 and Chevalier requires the minimum amount. Using glutenin, the quantities of $\mathrm{HCl}$ required decrease in order Hokudai No. 1, Golden Melon and Chevalier.

(9) From the results of the preceding experiments, i. e. the changes of the turbidity and the surface tension and the results of the determination of free amino nitrogen, it can be deduced that the $P_{I I}$ value of the isoelectric point of the water soluble protein is the lowest in Golden Melon, that of the $10 \% \mathrm{NaCl}$ solution soluble protein decreases in the order Golden Melon, Chevalier and Hokudai No. 1, that of the hordein decreases Chevalier, Hokudai No. 1 and Golden Melon, while that of the glutenin decreases Chevalier, Golden Melon and Hokudai No. 1.

(10) The specific rotatory power of the water soluble protein in an alkaline solution is the largest in Golden Melon, that of the $10 \% \mathrm{NaCl}$ solution soluble protein alkali solution decreases in the order Golden Melon, Chevalier and Hokudai No. 1, and that of the hordein in an alkaline solution decreases in the order Chevalier, Hokudai No. 1 and Golden Melon.

\title{
QUINOLINE AND ACRIDINE SYNTHESIS.
}

\author{
By Konomu Matsumura.
}

(Received Oct 2nd., 1926.)

I. 7-Iodo-5-amido-8-hydroxy-quinoline.

7-Iodo-5-nitro-8-hydroxy-quinoline (I) was obtained by iodination of 5-nitro-8-hydroxy-quinoline. Orange needles. F. $249^{\circ}$ (decomp.)

7-Iodo-5-amido-8-hydroxy-quinoline was obtained by reducing (I) with $\mathrm{SnCl}_{2}$ and conc. $\mathrm{HCl}$. Light yellowish needles. It softens at ca. $147^{\circ}$ and melts at $157^{\circ}$. Picrate : reddich brown needles, F. $159^{\circ}$ (decomp.). 